\title{
Marketing of Library and Information Services in University Libraries: A Case Study of Usmanu Danfodiyo University Library, Sokoto-Nigeria
}

\section{Kudirat Abiola Adegoke*}

ICT Librarian, Usmanu Danfodiyo University, Sokoto, Nigeria

\begin{abstract}
Marketing and promotion play a very vital role in creating awareness for library and information products and services. This paper discusses the importance of marketing and promotion in academic libraries with particular reference to Abdullahi Fodiyo Library Complex, Usmanu Danfodiyo University, Sokoto. The paper also reports marketing strategies employed by Abdullahi Fodiyo Library in promoting and attracting more library clientele as well as keeping them for long in the library. The paper concludes by advising librarians to wake up to promote their libraries through advertisement, exhibitions and displays, publicity, public relations to mention but few.
\end{abstract}

Keywords: Marketing; Promotion; University libraries; Information services; Library services

\section{Introduction}

Over the years, academic libraries have been depending on their parent institutions for a number of things ranging from funding to the publicity of their services. This, according to some scholar in the field of librarianship, has not been working very well for the libraries as Madhusudhan [1] reported that "Librarians and information specialists have debated the idea of marketing for the information sector. Several things have compelled librarians to learn about marketing and begin doing it" especially now that the whole world had turned to a global arena where time, space, geographical location/distance is no longer a barrier. It is obvious that academic libraries are experiencing rapid change in the use and mode of access to their resources and services; this can be attributed to emerging information technology which led to the creation of a new gateway for delivering information services to library clientele. Information products and services in a multiplicity of formats have made libraries and information centres to publicize the arrival and existence of some of their resources to clientele. Some years back, few clientele visit libraries regularly particularly students except during the examinations period when they need to read their personal notes for the benefit of passing their examinations. Considering the role of academic libraries as libraries attached to higher institutions of learning above the secondary level, which are responsible for providing information resources and services to support teaching, learning and research needs of students, staff and other clientele of their institutions. Academic libraries serve complementary purposes such as supporting the research of the University, faculties and students. The support of teaching requires material for learning and research and of what use are the library resources if there are no clientele to effectively utilize them. University library clientele are diverse with varying information needs. These library clientele include undergraduate and postgraduate students, visiting researchers, academic staff and other staff of the University. To a large extent, the library is often regarded as the heart of the intellectual system of the university or better still the nerve centre of the University. Aguolu [2] posited that university libraries are integral part of the university system. He added that, they should not exist as inertia of knowledge, but as dynamic instrument of education to enable their parent institutions to achieve their goals.

\section{Usmanu Danfodiyo University Library is a complex system comprising the following}

The Main Library (Abdullahi Fodiyo University Library)

\section{The Law Library located at the Faculty of Law}

The Medical and Veterinary Sciences Library located at the City Campus

The School of Matriculation Studies Library located at the School of Matriculation Studies

The Pharmaceutical Sciences Library temporarily located at Usmanu Danfodiyo University Teaching Hospital (UDUTH). The Abdullahi Fodiyo Library (AFL) (Main Library) is located at the permanent site of the Usmanu Danfodiyo University, Sokoto-Nigeria. The Library was established in October 1977 in order to provide effective services to the University Community. It is housed in a magnificent building that includes stacks, reading areas, periodicals or serials area, electronic library (e-library), internet cafe, administrative division, reception, conference room and circulation area. The collection has over 3 million volumes of books and journals covering a wide range of disciplines, particularly Science related courses, Arts and Humanities, Medicine, Medical Laboratory, Veterinary Science, Social Sciences, Agriculture, Pharmacy and other special collections on Arabic and Islamic Studies. Abdullahi Fodiyo Library has over 10,000 registered users which can be sub-divided into four categories: academics and non-academic staff, post-graduate students, undergraduate students, research scholars, and other users from different universities/institutions who also use the library's collections. The library has eighty four (84) professional staff and fifty two (52) junior staff (comprising of clerical, administrative and para-professionals) deployed all over the branches. Abdullahi Fodiyo Library provides access to both print and electronic informational and instructional resources to strengthen the University's performance of its teaching, learning research, and community service missions by:

a. Acquiring relevant materials, collections, and services that support the aims and objectives of the University;

*Corresponding author: Kudirat Abiola Adegoke, ICT Librarian, Usmanu Danfodiyo University, Sokoto, Nigeria, Tel- +2348038949317; E-mail: adegoke.kudirat@udusok.edu.ng

Received March 29, 2015; Accepted April 30, 2015; Published June 05, 2015

Citation: Adegoke KA (2015) Marketing of Library and Information Services in University Libraries: A Case Study of Usmanu Danfodiyo University Library, Sokoto-Nigeria. Intel Prop Rights 3: 143. doi:10.4172/2375-4516.1000143

Copyright: (c) 2015 Adegoke KA. This is an open-access article distributed under the terms of the Creative Commons Attribution License, which permits unrestricted use, distribution, and reproduction in any medium, provided the original author and source are credited. 
b. Providing added value to information resources by processing an assisting clientele in using the library resources;

c. Developing information services accessible by the University community both within and outside the campus;

d. Developing Library orientation and user's course for the University staff and students so as to make effective use of the library and its facilities;

e. Providing supportive service to clientele in the areas of using e-resources and as well as facilitating the retrieval of online resources;

\section{f. Providing internet and CD-Rom search for library clientele;}

g. Promoting the subscribed Universities e-resources by organising regular clientele training and publicity.

\section{Statement of the problem}

It has been observed by many researchers that most academic libraries do not market their information resources and services very well; this is responsible for the low patronage and underutilization of information resources and services by library clientele observed that marketing library and information is not practiced as expected, this statement is in line with the report of Kaur, Rani [3] that library resources are so expensive, but often remain underutilized resulting in wastage of money, time, energy and space. Also, said that "University libraries invest huge amount of money on collection development, processing and storage of information resources" and to ensure maximum utilization of these resources, there is the need for librarians to embark on publicity or sensitization of clientele so as to promote the use of their services. So also Carrington [4], observed that one of the problems or deficiencies faced by library is that of improper dissemination of library services to the target audience and that is one of the reasons for the low usage of library materials and facilities. In view of the above, it is observed that in recent time, Abdullahi Fodiyo Library is experiencing an exponential growth in its resources and clientele' population, this rapid growth is as a result of some marketing strategies put in place to persuade clientele to make use of the library rich collections.

\section{Research questions}

What are the types of information resources that are available in Abdullahi Fodiyo Library Complex?

What are the marketing strategies used by Abdullahi Fodiyo Library

\section{Objectives of the study}

To identify the available information resources and services in Abdullahi Fodiyo Library

To unveil the strategies used by Abdullahi Fodiyo Library in marketing its resources and services.

\section{Significance of the research}

The literature reveals that there is no similar study being conducted elsewhere, thus it is expected that this study provides the basis for further research in this field. The outcome of the study contributes to new knowledge in marketing library resources. Thus the study provides a comprehensive background and current scenario of marketing strategies used in Abdullahi Fodiyo Library Complex, Sokoto-Nigeria.

\section{Library and information services in Abdullahi Fodiyo library}

University libraries are established to provide information resources and services in order to support the purpose of the university. Sees information services as services provided by the library which draws attention to information possessed in the library in expectations of a demand [5] defined library services as help or assistance given to users in their quest for information resources. Various forms of publicity should encourage people to use the library. This includes welcome address delivered by librarians to users - staff and students of the founding body especially during the orientation programme of the fresh students, exhibition and display of books and sharing of circulars and University news bulletin. Abdullahi Fodiyo library is divided into different sections, some of these sections are directly involved in the marketing and promotion of library products and services; examples are the circulation, reference, information and communication technology (ICT), audio-visual units, and serials.

\section{Circulation section}

This is first section of the library that promotes the image of the library. The section serves as the public relations unit of the library due to the fact that the staff of the circulation section is directly involved in daily interaction with the library clientele. The section performs the following responsibilities;

\section{Registration of all readers}

2. Dissemination of information to all library staff and clientele

3. Displaying of new arrivals (i.e. library informational/educational materials)

4. Compiling and maintaining users' statistics

5. Keeping records of all borrowed and overdue books

6. Maintaining records of inter-library loan transactions

7. Charging and discharging of library resources

8. Assisting library portals in controlling theft

9. Clearing of the final year students

10. Keeping the overall statistics of all registered users of the library both staff and Students

\section{Reference section}

This section is responsible for meeting the information needs of library users in two ways i.e. direct and indirect. The direct service is providing library user's needs by interviewing and directing users to where to locate information while the indirect is regarded as behind the scene activities such as compiling list of required books, bibliography, indexing and abstracting.

\section{ICT division}

This division is responsible for providing free access to e-resources through the provision of free Library Café services and CD-Rom search. The division supports and promotes the institutional registered database resources such as Elsevier Science Direct, Hinari, Agora, Oare, Ebscohost, Virtual library and other relevant open source websites. The division is also responsible for digitizing the local contents of the virtual library project of Usmanu Danfodiyo University, Sokoto. Furthermore, the division uses internet services to promote library products and services by disseminating online information on the University website 
as well as creating links on the library portal to advertise library products and services particularly the new arrivals, announcement of days of users training, URL of the library databases/ e-resources and other library special functions.

\section{Audio-visual section}

Stores and preserves all types of instructional materials such as projectors, slides, video, audio, microform and microfilm and so on. Users can only operate these instructional materials under supervision of a qualified librarian known as Audio-visual Librarian. Instructional materials are good for recreational purposes.

\section{Types of library resources in Abdullahi Fodiyo library}

The available library resources in Abdullahi Fodiyo Library are as follows:

(a) Print Resources: These resources are books, journals, newspapers, magazines and pamphlets, Bound copies of e-journals, documents generated within the university(Local Contents), proceedings of government and its parastatals, documents on Africaand America e.t.c.

(b) Non-Print Resources: Otherwise known as electronic resources or audio-visual materials. These are soft copies of information that can only be viewed through the use of compatible hardware or application of information and communication technology. Electronic resources can be found in slides, CD-Roms, microforms, internet, audio cassette, video cassette and other storage devices. These resources are called e-books, e-journals, e-zines, e-documents, microfilms e.t.c

(c) Reference Resources: This type of resources offer information for research and provide facts about the document and they provide easy access and retrieval to information. Reference resources are as follows: encyclopeadia, dictionaries, hand books or manuals, biographical sources of information, atlas, prospectus, directories, gazetteers, almanacs, and so on. Mamman S [6] observed that reference service if properly utilized can boost the image of the library and can promote research. He submitted that reference work is the personal assistance to individual seeking information.

\section{Literature Review}

Significant research on marketing has been carried out in Nigeria and around the world to encourage librarians to improve on marketing their products and services.

\section{Concept of marketing}

Shapiro [7] observed that marketing mix can be applied in marketing library and information services that is the four P's product, price, place and promotion. Products in Librarianship refer to services or general reference and information services offered by the library. Products are the information, reference, and supplementary services that add value to the traditional library services such as personal assistance, referral services, on-line data base searches, document delivery and interlibrary loan. Pricing in the library is usually that of time and effort the user spends in travelling to the library as well as the time and effort spent in searching for and examining library resources and cost of a forgone alternative the products offered. Price is important in marketing in the world of information as it is elsewhere. Kotler $\mathrm{P}$ [8] described the 4 Ps of marketing: product, place, pricing, and promotion. Price can be expressed in currency; in the library, price can be used to express the value of information services: such as CD-Rom or a fee of a service or membership. Abdullahi Fodiyo Library charges fifty naira ( $¥ 0$ ) as library membership fee for all fresh students of Usmanu Danfodiyo University. A reasonable amount of income comes from photocopying services, fines charged on overdue books, fees charged on space allocation, printing and scanning services. Place include coverage, distribution channels, inventory, locations, and transportation; and Promotion is done through advertising, personal selling, and public relations.

\section{Public relations}

Public relation is a planned and sustained effort to establish and maintain goodwill and mutual understanding between the library and users. Publicity is given to products and services by various advertising methods. For example, University bulletin, website and general study course (GST 104) entitled "Use of Library and Study Skills" are used for disseminating information related to programmes and activities in the library.

\section{Concept of Promotion}

Promotion is essentially the means or ways of informing or persuading clientele on what you do and what you can do. The benefits for those who promote their library services include:

increased patronage and effective utilization of library resources,

increased value in the organization,

education of clientele and changed perceptions

To expand the services area the library has branches, electronics access, friends of the library and so on. Promotion includes utilizing persuasive information about general information services and communicating this information to target market segment that are potential clientele. Five kinds of promotion include, publicity, public relations, personal representative, advertising and sales promotion. In Librarianship, concepts like building clientele relationships, branding and repackaging of information resources, marketing library services, marketing strategy and planning are very fundamental to the promotion of library services.

\section{Display and Exhibitions}

Davidson [9] stressed the importance of marketing library and information services through displays and exhibitions. According to him exhibition can boost current awareness in the library because it allows library clientele to know the existence of materials in the library. The author is of the opinion that for the public confidence to be fully won, librarians should be able to carry along the community members by organizing library orientation, talks and seminar on the importance of displays and exhibitions.

Shapiro [7] wrote that library displays racks are very good forms of advertisement in the library. Display racks should be placed in strategic areas of the library where it would draw attention of the clientele, and the shelves should be boldly and clearly labelled for easy identification and retrieval of information resources.

\section{Advertisement}

Another strategy of marketing library and information services is by advertisement [10] express the role of advertisement in Nigeria economic growth and defined advertisement as any paid form of nonpersonal presentation and promotion of ideas, goods and services by an identified sponsor. Going by the above definitions and concept of 
marketing implies that advertising is a powerful strategy in marketing library and information services. The advertisement for marketing library and information services can be paid newspaper advertisement, radio or television transmission to communicate the services of library and information centre to its public and those who will need the service. Amechi [11] opined that posters should be developed much more. A series of posters should be prepared each one emphasizing a special facet of library services. They should be in colour and design, which means that the services of professional commercial artist should be employed. Publicity is defined by Sharman [12] as any information about individual, product, service or an organization that is distributed to the public through the media. It is neither paid for nor controlled by sponsor. Publicity is often used to launch new product, brand or service and also to rekindle interest in matured product or services. Publicity is always an important part of promotional programme and commonly supported by advertising.

\section{Strategies for Marketing Library and Information Ser- vices in Academic Libraries}

Strategy is a mechanism for coping with a complex and changing environment. Generally, the concept of strategy relates to corporate/ organizational strategy that guides the corporation or organization as a whole towards the attainment of its goals. Abdullahi Fodiyo Library introduced some products and services in order to sensitize and maintain good relationships with its numerous clientele. Among these efforts are the introduction of current awareness service; exhibition and display, selective dissemination of information; bulletin boards; complaints/suggestion boxes, clientele education course, electronic bill board, audio-visual services, online dissemination of information via the internet technology by creating links for current information on the library portal. Eye-catching displays, interactive web sites, aggressive advocacy, advertising, direct marketing, book sales, friends' groups, contests, good media relations, public presentations and other new technologies. Knowledgeable and enthusiastic staff members are also great promotion tools used to persuade the library users. The marketing strategies used by Abdullahi Fodiyo Library are discussed below. Abdullahi Fodiyo Library displays all its Arabic special collections, reference materials like biography of who is who in Nigeria, gender issues on both males and females at the strategic places or corners within the library in different show glasses. Electronic resources in CD-Roms are also displayed for awareness creation and they are made available to users free of charge upon requests for access. Current information on scholarships and other opportunities from newspaper, magazines and internet are photocopied and placed on the notice board for users' consumption.

\section{Publicity}

Wider publicity is given to Abdullahi Fodiyo Library products and services by various ways. For example, banners, Usmanu Danfodiyo University website and library portal are used for dissemination of information related to the various programmes and activities being performed by the library including the specific ventures such as conducting of the workshops/seminars/users courses. Wider Publicity is given to all the training programmes being conducted by the library.

\section{Library Orientation}

Every institution of higher learning organizes orientation programme for fresh students jointly or on departmental basis. Usmanu Danfodiyo University organises its own on faculty basis within a period of one week. This programme is usually handled by the Student Affairs
Division upon completion of students registration exercise. The essence of this programme is to introduce fresh students to life in the University and as well as taking a virtual tour to the University libraries through a power point presentation usually designed and presented by the library orientation committee members.

\section{Users Education}

Users' education is a compulsory one credit unit course taught under general studies (GST 104) in Usmanu Danfodiyo University Sokoto. It is compulsory for undergraduate students of the institution particularly the newly admitted students. The course is one of the strategies used by the University Library staff to bring students closer to the library. The course introduces students to the library operations, services and facilities. The aim of user education in Usmanu Danfodiyo University, Sokoto is to enable the students use the library effectively with minimum problems for the purpose of learning, research and recreation.

\section{Environment}

The writer observed that many libraries operate from a temporary building with inadequate space, shortage of chairs and tables, poor ventilation and faulty fans. This can discourage users from patronizing the library. In Usmanu Danfodiyo University Libraries, the story is different, Abdullahi Fodiyo Libary complex has over 6000 sitting capacity, its collections are separated according to faculties in a fully air conditioned environment, Abdullahi Fodiyo Library also provides television lounges at different locations for both male and female users of the library, this is done to keep the students current and make them stay long in the library. This is in line with the view of Adams $[13,14]$ that reading can be effective and interesting if it is done in a conducive environment.

\section{Conclusion}

In view of the significant role marketing library and information services play in creating awareness in library services, librarians must ensure that they put in more efforts in the aspect of marketing and promotion of their library products and services through advertisement, exhibitions and displays, publicity, public relations to mention but few.

\section{Recommendations}

The following recommendations were made to enhance the quality of marketing library and information's services in academic libraries.

1. As a result of the exponential growth in the use of Abdullahi Fodiyo Library complex, the management needs to constantly update the existing resources and subscribe to more electronic database so as to maintain the current level of patronage and as well as attracting more users.

2. Library Orientation for all users must be on a continuous basis and anchored by the librarians so as to make the exercise a fruitful one. Also librarians must divide users into small group for effective participation and understanding of some practical oriented aspect of the orientation.

3. Academic Librarians should not wait for their management to publicize their materials for them; rather they should strategies on how to effectively apply the promotional tools in marketing their products and services.

\section{References}

1. Madhusudhan M (2008) Marketing of Library and Information Services and Products in University Libraries: A Case Study of Goa University Library". Library Philosophy and Practice (e-journal). Paper 175. 
Citation: Adegoke KA (2015) Marketing of Library and Information Services in University Libraries: A Case Study of Usmanu Danfodiyo University Library, Sokoto-Nigeria. Intel Prop Rights 3: 143. doi:10.4172/2375-4516.1000143

Page 5 of 5

2. Aguolu CC, Aguolu I E (2002) User Education In Nigerian University Libraries. Libraries and Information Management in Nigeria. ED-LINFORM Services Maiduguri.

3. Kaur A , Rani S (2007) Marketing of Information Services and Products in University Libraries of Punjab and Chandigarh (India): An Exploratory Study. Electronic Journal of Academic and Special Librarianship 8.

4. Carrington A (2005) Use of posters in Exhibition: Melbourne success press.

5. Katz W (1999) Introduction to Reference Works: Basic Information Source, New York: Mc Graw-Hill P.24

6. Mamman S (2003) Theoretical Approach of Marketing Library services. Prentice Hall, New York.

7. Shapiro K (1999) Digest of statistics in Colleges of Education in Nigeria Abuja UNESCO Bulletins for libraries. Blackwell, New York.
8. Kotler P (1983) Marketing for non-profit organizations. Prentice-Hall of India New Delhi.

9. Davidson S (2001) Library Display as a current awareness service. NigerBiblios 14.

10. Amechi A (1991) Information Approach, Strategies in Libraries. H. W. Wilson, New York.

11. Sharman (2009) Poster for Advertisement. Clive Bindley press, Indiana.

12. Nwokoye J (2001) Essentials for Research Methodology for Nigeria Educators University press Ibadan.

13. Adams B (2008) Marketing concept for libraries and information services. Library Association, London.

14. Ranganathan S (1988) Five laws of library science. 2nd edition, Sarada Ranganathan Endowment for Library Science, Bangalore. 